7 Kotecha B, Fowler S, Topham J. Myringoplasty: a prospective audit study. Clin Otolaryngol 1999;24:126-9

8 Vartiainen E, Nuutinen J. Success and pitfalls in myringoplasty: follow-up study of 404 cases. Am J Otol 1993;1:301-5

9 Sckolnick JS, Mantle B, Li J, Chi DH. Pediatric myringoplasty: factors that affect success - a retrospective study. Laryngoscope 2008;118:723-9

10 Packer P, Mackendrick A, Solar M. What's best in myringoplasty: underlay or overlay, dura or fascia? J Laryngol Otol 1982;96:25-41

11 NCSS, PASS \& GESS: Statistics, Graphics, Power Analysis, Sample Size \& Microarray Analysis. In: http://www.ncss.com [5 May 2009]

12 Lee P, Kelly G, Mills RP. Myringoplasty: does the size of the perforation matter? Clin Otolaryngol 2002;27:331-4

13 Gersdorff M, Garin P, Decat M, Juantegui M. Myringoplasty: long-term results in adults and children. Am J Otol 1995;16: 532-5

14 Singh GB, Sidhu TS, Sharma A, Singh N. Tympanoplasty type I in children - an evaluative study. Int J Pediatr Otorhinolaryngol 2005;69:1071-6
15 Hydén D. Ear drum perforations in children after ventilation tube treatment. Int J Pediatr Otorhinolaryngol 1994; 29:93-100

16 Blanshard JD, Robson AK, Smith I, Maw AR. A long term view of myringoplasty in children. J Laryngol Otol 1990;104: $758-62$

Address for correspondence:

Dr Johanna Westerberg,

Department of ENT,

Vrinnevi Hospital,

Gamla Övägen 25,

60182 Norrköping, Sweden

Fax: +46 11223129

E-mail: johanna.westerberg@gmail.com

Dr J Westerberg takes responsibility for the integrity of the content of the paper

Competing interests: None declared

The Journal of Laryngology \& Otology (2011), 125, 132.

ERRATUM

(c) JLO (1984) Limited, 2011

doi: $10.1017 / \mathrm{S} 0022215110002768$

\title{
Ten-year myringoplasty series: does the cause of perforation affect the success rate?
}

J WESTERBERG, H HARDER, B MAGNUSON, L WESTERBERG, D HYDÉN

doi 10.1017/S0022215110002069, pp. 126-132 Published by Cambridge University Press, November 2010

In the published version of this paper, the following figure legends were published:

FIG. 1 Fascia profile used for a small perforation $(p)$ that does not reach the malleus. The tympanic membrane is dissected from the malleus shaft. A short horizontal slit is made in the fascia and the malleus tip is passed through. The inferior half of the manubrium will thus be located on the lateral surface of the fascial transplant. Bony septa are removed at the tubal threshold as well as the hypotympanum, to achieve a good overlap.

FIG. 2 Fasica profile used for a large perforation (P). The tympanic membrane is dissected from all of the malleus shaft except for a small area on the tip. A horizontal slit is made in the fascia from the anterior edge to the centre. The fascia is placed with one 'tail' above and the other below the umbo. The preserved attachment at the umbo prevents lateralisation of the transplant.

These figure legends should read:

FIG. 1 Fascia profile used for a small perforation ( $p$ ) that does not reach the malleus. The tympanic membrane is dissected from all of the malleus shaft except for a small area at the tip. A horizontal slit is made in the fascia from the anterior edge to the centre. The fascia is placed with one 'tail' above and the other below the umbo. The preserved attachment at the umbo prevents lateralisation of the transplant.

FIG. 2 Fascia profile used for a large perforation (P). The tympanic membrane is dissected from the malleus shaft. A short, horizontal slit is made in the fascia and the malleus tip is passed through. The inferior half of the manubrium will thus be located on the lateral surface of the fascial transplant. Bony septa are removed at the tubal threshold as well as the hypotympanum, to achieve a good overlap.

Also in this paper, the fourth sentence of the 'Hearing results' subsection of the 'Results' section was published as: life.

In 84 per cent of ears, the post-operative air conduction, measured as PTA, was $\geq 30 \mathrm{~dB}$, a level known to be adequate for daily

It should read: life.

In 84 per cent of ears, the post-operative air conduction, measured as PTA, was $\leq 30 \mathrm{~dB}$, a level known to be adequate for daily

Reference

1 Westerberg J, Harder H, Magnuson B, Westerberg L, Hydén D. Ten-year myringoplasty series: does the cause of perforation affect the success rate? J Laryngol Otol 2011:125:126-132 